\title{
BREEDING GRAIN CROPS TO INCREASE ADAPTABILITY
}

\author{
(review)
}

\section{I.A. RYBAS'}

I.G. Kalinenko All-Russian Research Institute of Grain Crops, Federal Agency of Scientific Organizations, 3, ul. Nauchnyi gorodok, Zernograd, Rostov Province, 347740 Russia, e-mail RybasIA@yandex.ru, vniizk30@mail.ru Received September 6, 2015

Abstract

The most essential feature of promising varieties is their adaptability, i.e., an ability to withstand environmental effects, which reduce productivity. Adaptation under plant-environment interaction, and the use of self-regulation mechanisms of yield formation and habitat-forming environmental processes influenced by plants take a central place in the evolution theory and plant breeding (Z.V. Andreeva et al, 2014). The review considers the adaptive potential of grain crops and the main concepts, characteristics and tasks of plant breeding for adaptability. The purpose of such breeding is to obtain the varieties with high resistance to unfavorable conditions. The concepts of stability, plasticity, homeostasis and resistance to stressors are discussed. In a broad sense, the genotype-environment interaction reflects plant response to any changes of the environment. In a narrower sense, the concept is used to describe the productivity change of genotypes in different environmental conditions. This interaction is crucial to increase crop production. The interactions and interrelations of genotype and environment are various and complicated. They greatly depend on genotype and a factor chosen as environmental agent or conditions (V.A. Zykin et al, 2005). A slight difference between genotypic potential and its phenotypic manifestation indicates a less response of a particular genotype to the environmental factors. Various methods are helpful to identify potential productivity and adaptability of the varieties. The estimates of adaptability and plasticity allow to determine reliably the differences among breeding material and gives an additional information to select valuable parental forms possessing adaptive traits. Special breeding methods which depend on environmental conditions and a phase of plant ontogenesis are necessary to create crop varieties and hybrids that have a good adaptability (A.P. Golovchenko, 2001).

Keywords: plant breeding, adaptability, stability, plasticity, homeostasis, tolerance (resistance) to stressors

One-size-fits-all approach to environmental management systems and violation of requirements to planting of cultivated species and varieties in strict compliance with their adaptability, i.e. in edaphoclimatic macro-, mezo- and microzones optimal for their cultivation, contribute to decline in agriculture. Progress in this area is attributed to extensive use of methods of plant breeding for adaptability and introduction of modern seed breeding techniques [1]. Plant breeding plays a crucial role in crop production with a focus on steady increase in yield, sustainability, efficient use of resources and energy, and nature conservancy [2]. This generally makes sense, as only $10 \%$ of more than 14 billion ha of agricultural lands worldwide are characterized by favorable conditions for cultivated crops [3]. With regard to other lands, high yield is constrained by various limiting factors.

Domestic and foreign literature offers various definitions of a norm of response to a range of changes of environmental conditions with regard to a variety, but all of them come down to adaptability. According to N.A. Lykova (2008), adaptiveness means preservation of viability and seed formation ability under nonoptimal (up to extreme) conditions [4]. According to A.A. Zhuchenko (1988), increase in yield is inextricably connected with resistance of crops to effect of factors, causing decrease in productivity. It has been argued that the contribution of plant breeding to increase in yield of major agricultural crops has reached $40-80 \%$ 
over the last 30 years. Biological component, most significantly the selective improvement of varieties and hybrids, will play an increasingly important part in yield gain and promotion of its quality [5]. Plant breeding for adaptability formed the basis for local inhabitant plant breeding, when resistance of plants to adverse climatic conditions and diseases was considered more valuable than recordbreaking harvest. Modern plant breeding is primarily focused on varieties with high adaptive potential. Such potential represents an inherently determined ability of adaptation to changing environmental conditions [6]. It can be also defined as a limit of resistance of cultivated plants to adverse factors, such as insect pests, weed infestation of crops, diseases, drought, soil salinization, or low temperatures [1].

Violation of adaptability requirements leads to dramatic rise in prices of agricultural products or prevents survival of introduced plants, like attempts of corn cultivation further north than its area, or tea plant cultivation in Transcarpathia [7].

Monitoring of ecological plasticity, stability and adaptability of varieties and hybrids is the key feature of breeding adaptive plants. The average value of a trait and environmental sensitivity of a trait are under independent genetic control [8-10]. Adaptability of a variety is assessed through decrease in average productivity trait. Resistance of varieties and lines to stressors, determined by difference between the minimum and the maximum trait $\left(\mathrm{Y}_{\min }-\mathrm{Y}_{\max }\right)$, is an important indicator of adaptability and ecological plasticity. This is a negative indicator, and decrease in its absolute value leads to increase in stress resistance, i.e. broadens the range of adaptive abilities of a variety [11-13].

According to V.O. Ostroverkhov [14], ecological plasticity of plants means the ability to adapt to changing growing conditionsand, with regard to varieties, the ability to produce a good and high-quality yield under various edaphoclimatic and agrotechnical conditions. V.N. Mamontova [15] and others [16-18] define plasticity as a persistently high yield under various environmental conditions. When considering ecological plasticity as a relation between productivity and resistance, a somewhat different interpretation is offered: in this case genotype plasticity shall mean the degree of its response to improvement of growing conditions [19]. V.A. Zykin et al. [20] define this concept as an ability to consistently produce high yield (as compared with other varieties or hybrids) with genetically determined quality within a broad area, under sufficiently diverse weather and agrotechnical conditions. Other authors use this definition as well $[21,22]$.

Homeostasis theory as an ability of plants to maintain internal equilibrium and to fulfill the genetically determined potential of a variety at the phenotypic level under abnormal conditions is an integral part of breeding ecologically plastic varieties [23]. A state of homeostasis can be used as the main genotype evaluation criterion. Homeostasis of a variety is measured through its ability to less significant decrease in yield in case of impairment of cultivation conditions. The above mentioned is critical to obtaining both maximum and steady yield within a wide range of growing conditions [24-26]. Steady grain yield indicates high homeostaticity, while increased variability indicates low homeostaticity of a genotype with regard to the same limiting factors of the environment [24].

Genotypes with high homeostaticity provide less volatile productivity of plants within an agrocenosis and insignificant decrease in yield in case of close planting or adverse factors combined with close planting [27]. Homeostasis is associated with physiological «buffer capacity» (tolerance to adverse environmental factors) [28]. A variety shall be considered as buffer (stable) in case of stability of its yield with regard to a wide range of acting factors [29]. In a narrow sense, stability is inherent in varieties, where changes of environmental conditions do not affect the development of traits (stability regardless of yield or another trait). 
In a broad sense, it is the degree of deviation from mean with regard to response to change of conditions within a system (group) of genotypes in question (stability of high productivity). Stability is also considered as steady manifestation of a trait under various conditions [30], ability of genotypes to maintain a certain phenotype under various conditions, using specific regulatory mechanisms [31], adaptive response of a genotype, leading to correlation between changes of status of traits and properties of an organism, and changes of environmental conditions [32]. A.A. Zhuchenko [5] highlights a close connection between stability and adaptive potential of plants, which is manifested under various environmental conditions with various physiological, morphological and other adaptive responses.

During ontogenesis and phylogenesis plants are affected by various abiotic and biotic factors, complicated in terms of their combination, intensity and time of manifestation. At that, genotype-environment interaction of a certain nature is established [33]. It was demonstrated that, when comparing genotypes grown under different conditions, their degrees of productivity are not constant, but vary depending on conditions, i.e. in a narrow sense, genotype-environment interaction effect is observed [34]. A slight difference between genotypic potential and its phenotypic manifestation in contrast environments indicates a less response of a particular genotype to their change [35).

Various aspects of genotype-environment interaction and methods of its evaluation in plant breeding are the subject of wide speculation in professional literature [36-39], with regard to ecological breeding issues [40] and epistasis [41], resistance to diseases [42], in terms of various cultures [43-45] and depending on physiology of a variety [46].

Genotype-environment interaction is common biological phenomenon, statistically represented by nonadditivity of genotype and environmental effects, observed in determining various genetic parameters. Statistical approaches for evaluation of this interaction have been suggested, when testing varieties in several environments (variety $\times$ year, variety $\times$ area, variety $\times$ year $\times$ area), and when assessing general and specific combining ability of genotypes and a degree of dominance. Interaction and relations between a genotype and environment are significantly diversified and complicated by nature and the character of manifestation, and depend on a genotype and the factor considered as an environment or conditions [35, 47]. It is believed that evaluation of genotypeenvironment interaction gives an insight into stability and plasticity of genotypes in question. At that, plasticity and stability characterize modification abilities with regard to certain traits of plants [48]. It is established that a) adaptability is mostly related to plasticity or lack of stability; b) plasticity of various traits differs, but is related to the time of manifestation of a trait during ontogenesis; c) traits formed during long-term meristematic activity periods (habitus, the number of leaves, etc.) are more prone to environmental impacts and more plastic than quickly formed ones; d) plant breeding can be performed with regard to both high and low plasticity of a certain trait; e) special attention should be given to examination of traits responsible for adaptability of a variety to the conditions of cultivation area and thus affecting sustainable yield [17].

It has been argued that stability and response of a trait are opposite features of a genotype (i.e., a genotype can not be stable and responsive with regard to the trait in question at the same time) [31], and stability of yields limits the possibility of increasing yield by improvement of conditions, including agrotechniques, which is not universally true. Thus, strong drought-resistance genetic systems will support productivity under drought conditions, and a variety will provide a bigger yield gain in case of irrigation. At that, a variety which is not droughtresistant will provide no yield, but will show the same yield gain in case of irriga- 
tion, as compared with a drought-resistant variety. These abilities play an important role in adaptability and maintenance of homeostasis in plants. Maximum adaptability of genotype is ensured by plasticity of certain traits which, in their turn, determine stability of other traits [35]. Plasticity is related to adaptation mechanisms: ability to respond to environmental signals is genetically determines, while the degree of response may evolve due to effects of natural and artificial selection [49].

An ecological test shall be performed in order to determine the response of genotypes to environmental changes. An extended ecological test is particularly useful with regard to search of adaptability gene sources [50]. However, such test is expensive. The use of various preceding crops, planting dates, forms and doses of fertilizers, as provocative conditions, can be helpful. An ecological test of breeding material provides a large amount of data which can hardly be analyzed without the respective methodological approach and processing. Some approaches may only complement the data on biological properties of a genotype, which shall form the basis for decision on future use of samples in question [22, 51].

The works of K.W. Finlay and G.N. Wilkinson [52] is among those first focused on phenotypic stability analysis of genotypes during testing under various agroecological conditions. These authors have developed the statistical method to compare yield for a set of corn varieties, grown in several areas during several years. An improved mathematical model and a calculation procedure for interaction between genotypes and environmental factors were offered upon its adjustment [19]. This approach was rather commonly used in plant breeding to evaluate ecological plasticity and remains relevant both in Russia [35, 53-55] and worldwide [53-59]. Stability evaluation allows us to describe the ability of a genotype to combine high potential yield with minimum decrease in yield under adverse conditions. Later this method was partly updated 60, 61]. The approach offered by G.C.C. Tai [62] comes down to evaluation of genetic stability based on structural relations analysis. Genotype-environment interaction effect is considered as two components: linear response to environmental effects (statistical $\alpha$ ) and deviation from linear response (statistical $\lambda$ ). Ecological plasticity parameters $\alpha$ и $\lambda$ correspond to bi and $\sigma \mathrm{d} 2$ parameters according to S.A. Eberhart and W.A. Russell [19, 30, 62]. Both methods provide for graphic representation of results which makes the data easier for understanding. A method of behavioral evaluation for a set of genotypes in various environments has been developed as well. This method allows us to identify general and specific adaptability, to perform target breeding, to specify environments as breeding conditions and to divide a phenotypic population variance into general and specific adaptability variances to choose breeding methods [31, 63].

A so-called ecovalence [64] was offered for each variety representing to characterize the variability. The more this indicator differs from 0 , the stronger response of a variety to environment change it provides [64, 65].

A coefficient of response to improvement of growing conditions is used in evaluation of varieties. It represents a fraction, where the value of a studied trait of a genotype grown in improved conditions is a numerator, and the value of a studied trait of a genotype grown in less favorable conditions is a denominator [20]. V.A. Dragavtsev et al. [66] used a multiplicative coefficient to determine a homeostaticity, which is calculated using a ratio between increment in the average trait of a variety for several geographic points and the average trait under ecological gradient. Homeostaticity of varieties can also be calculated using a ratio between the average trait and the difference between its values under optimal and limited (severe) conditions [67].

Suggested identification of potential productivity and adaptability of vari- 
eties [68] is based on a ratio between an implemented general species adaptive response to certain conditions and the average yield for the compared varieties. This value is a response indicator for a certain set of varieties with regard to environmental factors in every certain year. Response of each tested variety to these factors can be determined by comparing its yield with the average yield for the variety using a percentage ratio, where the average genotype value is taken as $100 \%[68,69]$.

Some researchers assume that evaluation of genotypes using one or two methods is not sufficient for representation of their stability and plasticity. Application of several methods provides the most detailed information, but ranking with regard to all parameters shall be used in this case, and evaluation shall be performed using the rank sum obtained by each method [70, 71].

When using various methods to evaluate a variety ecological plasticity, awareness of their compatibility is crucial [72]. The character of correlations between parameters and relation between the same parameters and yield are reported to vary significantly. Strong positive relations allow us to choose one of these indicators without detriment to outcomes [20]. Lack of significant relations between yield and the indicators of response and stability suggests a possible combination of these parameters within one genotype [71]. When comparing three known methods [60, 67, 19], it was suggested to use the last one to evaluated ecological plasticity by the trait with mandatory consideration of its average value and the limits of its variation [21].

For the foreseeable future, agricultural progress will determine improvement in adaptation of agricultural systems and cultivated lands to time- and spatial-varying environmental factors. These breeding trends are characterized by agroecological targeting, related to better adaptation of new varieties and hybrids to local conditions, as well as knowledge-intensive cultivation techniques. Their main distinctive feature is a combination of high potential productivity (yield and its quality) and resistance to the most common local abiotic and biotic stressors, as well as dominance of a genotype over uncontrolled environmental factors [73). Effectiveness of such breeding is ensured by use of various methods for evaluation of ecological plasticity which differ by complexity of calculations and result interpretation. As an approach, creation of environments for identification of adaptive traits and features has been proposed. A number of problems should be solved in order to obtain highly adaptive genotypes for certain area, including a) determination of mechanisms of response to environment changes; b) choose of desired traits and properties; c) identification of effective methods for breeding material evaluation; d) specification of environments to identify such genotypes, etc. In developed countries, yield increase depends on genetics and breeding by $90-95 \%$, and on improvement of agricultural technologies only by 5-10\% [74].

Adaptability of a variety (hybrid) is a balanced combination of numerous traits, where the most valuable are preferred. Adaptability degree depends on both adaptation of a variety and specific conditions within an agrocenosis. The following requirements are applied to an adaptive variety: a) ecological plasticity (ability to provide at least average yield within a wide range of climate variations); b) heterogeneity of agro-populations (presence of plants differing in height, rooting depth, drought resistance, blooming period, etc.); c) early maturity (ability to grow and develop quickly); d) intensity (ability to respond quickly to improved growing conditions, for example, to precipitation); e) resistance to fungal and other diseases; f) resistance to insect pests and high regrowth in case of infestation [8].

Spring wheat variety Lutescens 62, released as early as in 1929 and cultivated on large areas in eastern, southern and central regions of the country, as well as winter wheat varieties Bezostaya 1 and Mironovskaya 808, grown on sev- 
eral million hectares in the USSR and cultivated in a number of countries, may serve as an example of ecologically plastic varieties. Genotype plays an increasingly important role in yield gain and steadying, and the contribution of a variety during regionalization amounts to $30-50 \%$, according to some sources [75].

Globally, continuous increase in yield is based on improvement of growing technologies and the achievements in plant breeding. Breeding of complementary varieties is considered rather challenging [1]. Modern varieties shall be adapted to mechanized sowing, planting, handling, and harvesting. Non-shattering grain crops varieties resistant to lodging are highly valuable. Mexico, India and other countries have made meaningful progress in wheat grain production over 15-20 years using short-stalked varieties, and have refused from its import completely. The highest yield achieved in field trials in India with improved technology) amounted to $10.2 \mathrm{t} /$ ha at $4.5 \mathrm{t} /$ ha on average. Early-ripening, drought resistant, and winter-hardy varieties, or varieties for irrigated or reclaimed lands may be required, depending on conditions in the area of cultivation. Reclamation of marginal lands (acid, salinized, or bogged soils, sands) also depends on results in plant breeding. This aspect is a matter of particular concern in some countries. In Brazil, the varieties which are not resistant to acid soils are not allowed to production [1]. Adaptations under moisture deficiency [76-78], drought [79, 80], thermal stress [81], and salinity [82] have been studied at various levels of plant organization in recent years.

A concept of habitat-forming and resource reclaiming (nature reclaiming) role of varieties, formulated by A.A. Zhuchenko [83], is especially noteworthy. In fact, this resource of plant breeding, despite its value, is undeesstimated. Decrease in reclaiming properties upon achievement of high potential yield is observed. Adaptation of modern varieties and hybrids is often insufficient to create high-yielding and environmentally sustainable agricultural systems and cultivated lands. As a result, only $25-40 \%$ potential yield is obtained because of insufficient (often decreasing) plants resistance to abiotic and biotic stresses. Effectiveness increases when several varieties are cultivated, differing by maturation timing, intensity of growth processes, and response to environmental challenges, soil fertility, and the preceding crops [1].

Thus, adaptability, as the most essential feature of promising varieties, shall be considered in breeding programs. The environment for variety cultivation should also be specified, considering the role of genotype-environment interaction. Estimation of potential productivity and adaptability, as well as evaluation of stability and plasticity of crop varieties allow us to determine the significance of observed differences and to reveal the sources of valuable traits for breeding programs.

\section{REFEREN C ES}

1. Korzun O.S., B ruilo A.S. Adaptivnye osobennosti selektsii $i$ semenovodstva sel'skokhozyaistvennykh rastenii [Peculiarities of adaptive breeding and seed production in cultivated plants]. Grodno, 2011 (in Russ.).

2. Z h u c h e n k o A.A. Sel'skokhozyaistvennaya biologiya [Agricultural Biology], 2000, 3: 3-29 (in Russ.).

3. Christianse n M. World environmental limitations to food and fiber cultures. In: Breeding plants for less favorable environments. NY, 1982: 1-11.

4. L y k o v N.A. Sel'skokhozyaistvennaya biologiya [Agricultural Biology], 2008, 1: 48-54 (in Russ.).

5. Zhuchenko A.A. Adaptivnyi potentsial kulturnykh rastenii (ekologo-geneticheskie osnovy) [Adaptive potential of cultivated plants - eco-genetic bases]. Kishinev, 1988 (in Russ.).

6. D e d y u I.I. Ekologicheskii entsiklopedicheskii slovar' [Encyclopedic dictionary on ecology]. Kishinev, 1989 (in Russ.).

7. V a vilov N.I. Teoreticheskie osnovy selektsii [Theoretical fundamentals of breeding]. Moscow, 1987 (in Russ.). 
8. Z h u c h e $\mathrm{n}$ k o A.A. Adaptivnaya sistema selektsii rastenii (ekologo-geneticheskie aspekty). Tom I, II [Adaptive plant breeding - eco-genetic aspects. V. I, II]. Moscow, 2001 (in Russ.).

9. Ved rov N.G. Materialy Mezhdunarodnoi shkoly «Aktual'nye zadachi selektsii $i$ semenovodstva sel'skokhozyaistvennykh rastenii na sovremennom etape» [Proc. Int. Conf. «Current problems of crops breeding and seed production»]. Novosibirsk, 2005: 72-77 (in Russ.).

10. K h a li p sk i i A.N. Materialy Mezhdunarodnoi shkoly "Aktual'nye zadachi selektsii $i$ semenovodstva sel'skokhozyaistvennykh rastenii na sovremennom etape» [Proc. Int. Conf. «Current problems of crops breeding and seed production»]. Novosibirsk, 2005: 559-563 (in Russ.).

11. Rosi elle A.A., H a mbli n J. Theoretical aspects of selection for yield in stress and nonstress environments. Crop Sci., 1981, 21(6): 943-946.

12. G o n c h a re n k o A.A. Vestnik RASKHN, 2005, 6: 49-53 (in Russ.).

13. S a p e ga V.A., T u r u m be k ov a G.Sh., S a p e g a S.V. Dostizheniya nauki i tekhniki APK, 2012, 10: 22-26 (in Russ.).

14. Ostrove rkhov V.O. V sbornike: Genetika kolichestvennykh priznakov sel'skokhozyaistvennykh rastenii [In: Genetics of quantitative traits in cultivated plants]. Moscow, 1978: 128-141 (in Russ.).

15. M m o n tova V.N. Selektsiya i semenovodstvo yarovoi pshenitsy [Bread wheat breeding and seed production]. Moscow, 1980 (in Russ.).

16. G e ras i m e n k o V.F. Sel'skokhozyaistvennaya biologiya [Agricultural Biology], 1981, 6: 938941 (in Russ.).

17. Z y k i n V.A. Vestnik RASKHN, 1992, 2: 23-26 (in Russ.).

18. Ozhogina L.V., K hizhnikova T.G., Ko ma rova S.P. Materialy Mezhdunarodnoi nauchno-prakticheskoi konferentsii «Sovremennye problemy $i$ dostizheniya agrarnoi nauki $v$ zhivotnovodstve i rastenievodstve» [Proc. Int. Conf. «Challenges and achievements of plant and animal science for agriculture»]. Barnaul, 2003: 62-65 (in Russ.).

19. Eberhart S.A., Russe11 W.A. Stability parameters for comparing varieties. Crop Sci., 1966, 6(1): 36-40.

20. Z y k i n V.A., M e s h k o v V.V. Nauchno-tekhnicheskii byulleten', 1986, 14: 3-13 (in Russ.).

21. Rozova M.A., Ya n c he n ko V.I., M e l'nik V.M. Ekologicheskaya plastichnost' yarovoi tverdoi pshenitsy $v$ usloviyakh Altaya [Eco-plasticity of bread wheat in Altai region]. Barnaul, 2010 (in Russ.).

22. Ziborov A.I. Otsenka ekologicheskoi plastichnosti sovremennykh sortov $i$ perspektivnykh linii yarovoi tverdoi pshenitsy v usloviyakh Priobskoi lesostepi Altaiskogo kraya. Kandidatskaya dissertatsiya. [Estimation of eco-plasticity in modern bread wheat varieties and lines under forest-steppe conditions in the Ob River basin of Altai Territory. PhD Thesis]. Barnaul, 2013 (in Russ.).

23. Yusu fov A.G. Sel'skokhozyaistvennaya biologiya [Agricultural Biology], 1983, 1: 25-35 (in Russ.).

24. S a p e g a V.A. Vestnik sel'skokhozyaistvennoi nauki Kazakhstana, 1988, 10: 24-28 (in Russ.).

25. T s i l'k e R.A. Sibirskii vestnik sel'skokhozyaistvennoi nauki, 1997, 1/2: 12-19 (in Russ.).

26. V a le k z ha $\mathrm{n}$ i n V.S. Ekologicheskaya plastichnost' $i$ stabil'nost' sortov $i$ linii yarovoi myagkoi pshenitsy po urozhainosti i elementam ee struktury v usloviyakh Priobskoi lesostepi Altaiskogo kraya. Kandidatskaya dissertatsiya [Eco-plasticity and stability of bread wheat varieties and lines with regard to productivity and its elements under forest-steppe conditions in the Ob River basin of Altai Territory. PhD Thesis]. Barnaul, 2012 (in Russ.).

27. Khangil'din V.V., Litvine nko N.A. Nauchno-tekhnicheskii byulleten', 1981, 1: 8-14 (in Russ.).

28. Alla rd R.W., B rads haw A.D. Implication of genotype - environmental interaction in applied plant breeding. Crop Sci., 1964, 4: 503-508.

29. B riggs F.N., K now les P.F. Nauchnye osnovy selektsii rastenii [Introduction to plant breeding]. Moscow, 1972 (in Russ.).

30. Zykin V.A., B e lan I.A., Yusov V.S., Nedorezkov V.D., I s magilov R.R., $\mathrm{K}$ a d i k ov R.K., I s l a m g u lov D.R. Metodika rascheta $i$ otsenki parametrov ekologicheskoi plastichnosti sel'skokhozyaistvennykh rastenii [Calculation and estimation of eco-plasticity in cultivate plants]. Ufa, 2005 (in Russ.).

31. K il' chevski i A.V., K hotyleva L.V. Genotip $i$ sreda $v$ selektsii rastenii [Genotype and environment in plant breeding]. Minsk, 1989 (in Russ.).

32. B u rdu n A.M., Lo patina L.M., Guida A.N., Loginov Yu.P., Maksi menko V.P. V sbornike: Teoreticheskie $i$ prikladnye aspekty selektsii i semenovodstva pshenitsy, rzhi, yachmenya $i$ tritikale [In: Wheat, rye, barley and triticale: theoretical and practical aspects of breeding and seed production]. Odessa, 1981: 169 (in Russ.).

33. Z y k i n V.A. V sbornike: Teoreticheskie osnovy selektsii i semenovodstva sel'skokhozyaistvennykh kul'tur v Zapadnoi Sibiri [In: Theoretical bases of breeding crops for western Siberia]. Novosibirsk, 1985: 9-19 (in Russ.).

34. F e d i n M.A., S i lis D.Ya., S m i ry a e v A.V. Statisticheskie metody geneticheskogo analiza [Statistical methods for genetic analysis]. Moscow, 1980 (in Russ.).

35. Co m s to k K.E., M o 11 K.H. Genotype and environment interactions. In: Statistical genetics and 
plant breeding. H.F. Robinson, W.D. Hanson (eds.). NAS-NRC, Washington, 1963: 164-196.

36. Free man G.H. Statistical methods for the analysis of genotype environment interactions. Heredity, 1973, 31(3): 339-354.

37. Hiil J. Genotype-environment interactions - a challenge for plant breeding. Agric. Sci. Camb., 1975, 85(3): 477-493.

38. Khotyle va L.V., T a r u t i n a L.A. Bzaimodeistvie genotipa i sredy. Metody otsenki [Genotype-environment interaction - methods for estimation]. Minsk, 1982 (in Russ.).

39. We s t c o t t B. Some methods of analysing genotype-environment interaction. Heredity, 1986, 56(2): 243-253.

40. Kil' c h e v s ki i A.V. Selektsiya i semenovodstvo, 1993, 3: 5-9 (in Russ.).

41. Fethi B., Moha med E.L.G. Epistasis and genotype-by-environment interaction of grain yield related traits in durum wheat. Plant Breed. Crop Sci., 2010, 2(2): 024-029.

42. Cherif M., Rezgui S., Devaux P., Harrabi M. Genotype $\times$ environment interactions and heritability of quantitative resistance to net blotch in Tunisian barley. Plant Breed. Crop Sci., 2010, 2(5): 110-116.

43. Ebadi-Segherloo A., Sabaghpour S.H., Dehghani H., Kamrani M. Screening of superior chickpea genotypes for various environment of Iran using genotype plus genotype $\times$ environment (GGE) biplot analysis. Plant Breed. Crop Sci., 2010, 2(9): 286-292.

44. Abo-Hegazy S.R.E., S e li m T., A s h rie A.A.M. Genotype $\times$ environment interaction and stability analysis for yield and its components in lentil. Plant Breed. Crop Sci., 2013, 5(5): 85-90.

45. G edif M., Yigzaw D., Tsige G. Genotype-environment interaction and correlation of some stability parameters of total starch yield in potato in Amhara region, Ethiopia. Plant Breed. Crop Sci., 2014, 6(3): 31-40.

46. $\mathrm{K} \mathrm{u} \mathrm{mak} \mathrm{ov} \mathrm{V.A.} \mathrm{Fiziologicheskoe} \mathrm{obosnovanie} \mathrm{modelei} \mathrm{sortov} \mathrm{pshenitsy} \mathrm{[Physiological} \mathrm{basis} \mathrm{of}$ wheat variety modeling]. Moscow, 1985 (in Russ.).

47. Z y k i n V.A., S h a m a n i n V.P., B e la n I.A. Ekologiya pshenitsy [Wheat ecology]. Omsk, 2000 (in Russ.).

48. Walt on P.D. Spring wheat variety trials in the Prairie Provinces. Can. J. Plant Sci., 1968, 48: 601-609.

49. P e re z d e la Vega M. Plant genetic adaptedness to climatic and edaphic environment. Euphytica, 1996, 92: 27-38 (doi: 10.1007/BF00022825).

50. $\mathrm{Z} \mathrm{hu} \mathrm{c} \mathrm{h} \mathrm{e} \mathrm{n} \mathrm{k} \mathrm{o} \mathrm{A.A.} \mathrm{Ekologicheskaya} \mathrm{genetika} \mathrm{kul'turnykh} \mathrm{rastenii} \mathrm{(adaptatsiya,} \mathrm{rekombinogenez,}$ agrobiotsenoz) [Eco genetics of cultivated plants: adaptability, recombinogenesis, agrobiocenosis]. Kishinev, 1980 (in Russ.).

51. Morgunov A.I., N a m ov A.A. Selektsiya zernovykh kul'tur na stabil'nost' urozhainosti: Obzornaya informatsiya [Breeding cereal crops for sustainable yield production - a review]. Moscow, 1987 (in Russ.).

52. Fin lay K.W., Wilkins on G.N. The analysis of adaptation in a plant-breeding program. Austral. J. Agr. Res., 1963, 14(2): 742-754.

53. Dobrutskaya E.G., Pivovarov V.F. Selektsiya $i$ semenovodstvo, 2000, 1: 28-30 (in Russ.).

54. S a p e g a V.A., T u r s u m b e k o v a G.Sh. Zemledelie, 2015, 2: $45-46$ (in Russ.).

55. Rybas' I.A., Gureeva A.V., Marchenko D.M. Dostizheniya nauki i tekhniki APK, 2014, 9: 17-19 (in Russ.).

56. Mohamed Ahmed S.B., Abdella A.W.H. Genetic yield stability in some sunflower (Helianthus annuus L.) hybrids under different environmental conditions of Sudan. Plant Breed. Crop Sci., 2009, 1(1): 016-021.

57. Mut Z., Aydin N., Bayramoglu H.O., Ozcan H. Stability of some quality traits in bread wheat (Triticum aestivum) genotypes. Journal of Environmental Biology, 2010, 31: 489-495.

58. D a s S., M is ra R.C., S in h a S.K., P a t t a $\mathrm{n}$ a i k M.C. Variation in streptomycin-induced bleaching and dark induced senescence of rice (Oryza sativa) genotypes and their relationship with yield and adaptability. Plant Breed. Crop Sci., 2010, 2(6): 139-147.

59. R a j a S., B a gle B.G., M o r e T.A. Drumstick (Moringa oleifera Lamk.) improvement for semiarid and arid ecosystem: analysis of environmental stability for yield. Plant Breed. Crop Sci., 2013, 5(8): 164-170.

60. M a r t y n o v S.P. Sel'skokhozyaistvennaya biologiya [Agricultural Biology], 1989, 3: $124-$ 128 (in Russ.).

61. M a rt y n o v S.P. A method for the estimation of crop varieties stability. Biom. J., 1990, 32(7): 887-893 (doi: 10.1002/bimj.4710320717).

62. Ta i G.C.C. Genotypic stability analysis and its application to potato regional trials. Crop Sci., 1971, 11(2): 184-190 (doi: 10.2135/cropsci1971.0011183X001100020006x).

63. Z y k i n V.A., B e 1 a n I.A., Y u s o v V.S., K o r n e v a S.P. Metodiki rascheta ekologicheskoi plastichnosti sel'skokhozyaistvennykh rastenii po distsipline «Ekologicheskaya genetika» [Estimation of eco-plasticity in cultivated plants (ecogenetics)]. Omsk, 2008 (in Russ.).

64. W ri c k e G. Über eine Methode zur Erfassung der őkologischen Streubreite in Feldversuchen. 
Z. Pflanzenzüchtung, 1962, 47(1): 92-96.

65. An i s'k o v N.I. Nauchno-tekhnicheskii byulleten', 1986, 14: 23-30 (in Russ.).

66. D ragavtsev V.A., Tsil'k e R.A., R e it e r B.G. Genetika priznakov produktivnosti yarovykh pshenits $v$ Zapadnoi Sibiri [Genetics of production traits in spring wheat from western Siberia]. Novosibirsk, 1984 (in Russ.).

67. Kh a ngil'd in V.V. V sbornike: Genetika kolichestvennykh priznakov sel'skokhozyaistvennykh rastenii [In: Genetics of quantitative traits in cultivated plants]. Moscow, 1978: 111116 (in Russ.).

68. Z hivotk ov L.A., M or o zova Z.A., S e k a t u e va L.I. Selektsiya i semenovodstvo, 1994, 2: 3-6 (in Russ.).

69. Malyavko A.A., Marukhle nko A.V., Borisova N.P. Kartofel' $i$ ovoshchi, 2012, 3: 10-11 (in Russ.).

70. Mal'chikov P.N., V'y ushkov A.A. V sbornike: Genetika, selektsiya i semenovodstvo sel'skokhozyaistvennykh (kul'tur k 100-letiyu Samarskogo NIISKH) [In: Genetics, breeding and seed production of cultivated plants: to $100^{\text {th }}$ anniversary of Samara Research Institute of Agriculture]. Samara, 2003 (in Russ.).

71. Evd o k i mov M.G. Selektsiya yarovoi tverdoi pshenitsy v Sibirskom Priirtysh'e. [Spring wheat breeding for Irtysh river basin of Siberia]. Omsk, 2006 (in Russ.).

72. Z $\mathrm{y}$ k i n V.A., B e la n I.A., R o s s e e v V.M. Materialy seminara «Problemy selektsii i semenovodstva v Zapadnoi Sibiri i Kazakhstane» [Proc. Seminar «Problems of breeding and seed production of field crops in western Siberia and Kazakhstan»]. Barnaul, 2001: 23-31 (in Russ.).

73. Z hu che nk o A.A. V sbornike: Strategiya adaptivnoi selektsii polevykh kultur v svyazi s global'nym izmeneniem klimata [Strategy for developing varieties and hybrids with regard to global climate change]. Saratov, 2004: 10-16 (in Russ.).

74. Dragavtsev V.A., Makarova G.A., Kochetov A.A., Kocherina N.V., Mirsk a a G.V., S in y avina I.G. Agrofizika, 2011, 1: 14-22 (in Russ.).

75. B orisovets T. Agroekonomika, 2000, 3: 30-32 (in Russ.).

76. S a e e dip o u r S. Activities of sucrose-metabolizing enzymes in grains of two wheat (Triticum aestivum L.) cultivars subjected to water stress during grain filling. Plant Breed. Crop Sci., 2011, 3(6): 106-113.

77. Aliakbari M., S aed-Moucheshi A., Hasheminasab H., PirastehAnosheh H., Asad M.T., Emam Y. Suitable stress Indices for screening resistant wheat genotypes under water deficit conditions. Agronomy and Plant Production, 2013, 4(10): 2665-2672.

78. Keshavarzi M., Miri H.R., Haghighi B.J. Effect of water deficit stress on grain yield and yield components of wheat cultivars. Agronomy and Plant Production, 2013, 4(6): 1376-1380.

79. K h a varinejad M.S., K a ri mov M. Study of genetic diversity among spring wheat genotypes in drought stress by advanced statistical analysis. Agronomy and Plant Production, 2012, 3(12): 590-598.

80. Varga B., Vida G., Varga-Laszlo E., Be ncze S., Ve is z O. Effect of simulating drought in various phenophases on the water use efficiency of winter wheat. Agronomy and Crop Science, 2015, 201: 1-9 (doi: 10.1111/jac.12087).

81. Feng B., Li u P., Li G., Dong S.T., Wang F.H., Kong L.A., Zhang J.W. Effect of heat stress on the photosynthetic characteristics in flag leaves at the grain-filling stage of different heat-resistant winter wheat varieties. Agronomy and Crop Science, 2014, 200: 143-155 (doi: 10.1111/jac.12045).

82. Bakhshi S., Ghorbanli M., Allahverdi Mamaghani M. Comparison of germination factors among some halophyte plants to salt stress. Agronomy and Plant Production, 2013, 4(6): 1281-1284.

83. $\mathrm{Z}$ h u che $\mathrm{nk}$ o A.A. Adaptivnoe rastenievodstvo (ekologo-geneticheskie osnovy). Teoriya i prakti$k a$ [Adaptive crop production (eco-genetic fundamentals) - theoretical and practical aspects]. Moscow, 2008 (in Russ.). 